stamp of all thinking and writing of this character. It is the exact opposite of the scientific frame of mind, and makes one think that the spread of science and the scientific spirit into all realms of thought is one of the two supreme needs of the age.

\section{Inauguration of the Mettur Dam and Reservoir}

Tre development of irrigation in India has taken another notable step forward with the recent completion of the Mettur Dam in the province of Madras, and the occasion of the official opening on August 21 was marked by an impressive ceremony when Sir George Stanley, the Governor of Madras, made the electrical contact which operated the sluice penstocks and released a huge volume of water from the impounded area. The dam and reservoir, which are to take the designation "Stanley", are located on the Cauvery River, 100 miles north-west of Trichinopoly and 180 miles south-west of Madras. The dam, one of the most massive structures of its kind in the world, contains $1,852,000$ cubic yards of masonry weighing $3,200,000$ tons; it has an over-all length of $5,300 \mathrm{ft}$., and a height of $176 \mathrm{ft}$. The reservoir will extend more than 40 miles north of the river, with a circumference of about 100 miles, and will have a capacity of $90,000,000,000 \mathrm{cub}$. ft. The catchment area is 15,700 square miles in extent and the total area to be irrigated will be rather more than $1,300,000$ acres, including some 300,000 acres at present without any form of irrigation. Pipes have been built into the dam to permit of the utilisation of some of the water for the generation of hydroelectric power in a scheme which is now under consideration by the Secretary of State. The cost of the Cauvery-Mettur undertaking is given as about $5 \frac{1}{2}$ million sterling. The idea was conceived about a century ago by Sir Arthur Cotton, but work was not begun until 1925 and benefited by the experience gained during the unprecedented floods of the previous year, which caused a revision and extension of the scheme. For his services in connexion with the work, Mr. Clement T. Mullings, who was chief engineer of the project from 1927 until 1931, has received the honour of knighthood.

\section{Chronology of Scottish Caves}

AN examination of the contents of a large cave at Southend, Kintyre, Argyllshire, by Mr. Hamilton Maxwell, on behalf of the Glasgow Archæological Society, has yielded in the course of digging through $10 \mathrm{ft}$. of deposit down to bed-rock a number of relics in bone, horn, bronze and iron, mostly belonging to the early iron age. According to a report in the Times of August 28, the object of the investigation was to ascertain the probable date of the erosion of the cave; and for this the date of about 4400 B.c. is now suggested. This conclusion is based upon a comparison with the Oban caves of Azilian date and the butt sites at Oronsay, explored by Messrs. Henderson, Bishop and Ludovic McL. Mann. The Oban caves have been taken as dating from about 13000 B.c. This gives, therefore, a dating for the Scottish levels of a raised beach at $27 \frac{1}{2} \mathrm{ft}$., 13000 B.C. ; a sunken beach at a depth of $20 \mathrm{ft}$., about 8700 в.c. ; a raised beach at $9 \frac{1}{2} \mathrm{ft}$., about 4400 B.c.; and a sunken beach at a depth of about $7 \mathrm{ft}$. at about 100 B.C.

\section{Meare Lake Village}

Excavations were resumed on the site of the Meare Lake Village on August 20 and will continue until September 8, or longer, should funds permit. The investigation is being carried on, as usual, under the auspices of the Somersetshire Archæological and Natural History Society, Dr. A. Bulleid and Mr. St. George Gray again being the field directors. The season's work will be directed to the exploration of two areas in the middle of the group of dwellings of the eastern half of the village. The first of these is a confused area of hummocks and hollows, of which the significance is not clear from surface indications. Apparently the mounds overlap and have been much mutilated superficially. The area is surrounded by a rough lias-stone wall, slight in height, of some $70 \mathrm{ft}$. in diameter. In a report on the work of the first week which appears in the Times of August 28, it is stated two clay floors of dwellings have been found under the stones. On the upper floor was one of the most ornate and best preserved weaving-combs of antler as yet found in the lake village remains. The second site under investigation is a dwelling mound of approximately $\mathbf{3 5} \mathrm{ft}$. diameter, which apparently has three floors, the uppermost being paved with small lias-stones. At this level, two much-defaced brass Roman coins of the fourth century were found. At lower levels, pre-Roman objects included pottery with 'late-Celtic' ornament, bronze finger-rings and a buckle and a brooch of La Tene III type. A clear glass bead with yellow spirals was found below the floors. Among the animal remains were bones of two beavers, traces of which are rarely found in Great Britain.

\section{Exçavations in Berkshire}

FURTHER particulars of the excavations on the Berkshire Downs to which reference was made in NATURE of August 18, p. 244, have been received from Mr. H. J. E. Peake. The site on which was discovered the skeleton of a dog was a round barrow on East Lockinge Down, which is mentioned in the bounds of Lakinge in a charter of A.D. 868. The remains were in the upper and larger of two holes in the chalk near the intersection of trenches dug across the barrow with the object of discovering the ditch, which was not visible on the surface. It was found that the highest point of the barrow is not in the centre. A small hole at the central point, about a foot in diameter, contained burnt human remains, but no grave furniture. The date suggested is the end of the Early Bronze or beginning of the Middle Bronze Age. The irregular round barrow in the parish of East Hendred, from which the remains of the two horses were obtained, was found to have no ditch. Beneath the skeletons of the horses were a number of small objects of Roman date, including fragments of an iron knife and the pin of a bronze 
fibula hinged to a La Tene coil. Elsewhere in the barrow were numerous fragments of Romano-British pottery and a small bronze hook. The exploration of Cuckhamsley, or Scutchermer Knob, which is known to have been rifled about a hundred years ago, provided no evidence of burial; but a number of fragments of pottery, including finger-tip ware, consistent with a fifth century B.c. dating were turned up, while $2 \mathrm{ft}$. above were potsherds and a fragment of copper or bronze of foliated design. The mound is evidently not a bronze age barrow nor the burial place of a Saxon king; what the purpose of this remarkable construction may have been has not been revealed.

\section{Quaternary Research in Ireland}

EARLY in 1933 a committee entitled "The Committee for Quaternary Research in Ireland" was founded under the chairmanship of Dr. R. Lloyd Praeger, with Prof. H. J. Seymour as treasurer and Mr. A. Farrington as secretary, the personnel of the Committee being representative of all the scientific bodies and universities of Ireland. The Committee succeeded in enlisting the support of Irish scientific societies, the universities and the Free State Government. The object of the research is to establish a chronology for late-glacial and post-glacial deposits in Ireland, and to study the history of the Irish flora and fauna. Prof. K. Jessen of Copenhagen, with his assistant $\mathrm{Mr}$. H. Jonassen, was invited to take charge of the research. One of the most important aspects of the scheme as conceived by the Committee is the training of Irish students from the universities in the methods developed in northern Europe, so that research centres may be permanently established in the country. Work was begun in the present summer, the first site to be examined being the wellknown bog at Ballybetagh in south Co. Dublin where many remains of Megaceros Giganteus have been found during the last hundred years. An extended tour will also be made for the uxamination of deposits in many other districts throughout Ireland. A list of well-dated recent archæological finds from peat bogs, compiled by Dr. A. Mahr, Director, National Museum, Dublin, forms the basis of this tour.

\section{Expeditions of the Smithsonian Institution, I933}

OwING to the period, variable in duration, but usually not inconsiderable, which must elapse before it is possible to publish in full the details of the valuable field-work which is carried out by the Smithsonian Institution in astrophysies, geology, biology and anthropology, the annual exploration pamphlet issued by the Institution is of considerable interest, as giving an early authoritative account of the various expeditions sent out during the year. The latest issue (Publication 3235), for example, which covers the activities of 1933, records the establish. ment of a new solar observing station on Mount St. Catherine, Sinai (G. C. Abbott), and deseribes the work of the Norcross-Bartlett Arctic Expedition (Capt. R. A. Bartlett), of a deep-sea expedition to PuertoRico (Paul Bartsch), a search for extinct marine mammals in Maryland (Remington Kellogg), particulars of the Hancock expedition to Galapagos (Waldo L. Schmidt), and zoological collecting in Siam (Hugh M. Smith). The greater part of the publication, however, is devoted to the activities of members of the Smithsonian staff in the investigation of the archæology and ethnology of the American Indian, the former a subject in which great progress has been made in recent years by the systematic application of scientific methods of excavation and correlation of results. Dr. Frank H. Roberts, Jr., has continued his excavations of Pueblo sites in the south. western United States, in which the development of Pueblo culture and more particularly of the Pueblo dwelling is being revealed. Dr. Walter Hough has also been engaged in studying an important aspect of Pueblo culture by tracing ancient canals in Arizona, while an earlier phase of Indian history has been illuminated by Mr. F. Setzler's cave and mound explorations in Texas and Louisiana. Dr. W. D. Strong has been engaged in the study of the archæology of Honduras and the Bay islands; while Miss Frances Densmore in her studies of Floridan music and Mr. John Harrington by oral inquiry among ancient members of Californian tribes have recorded material which, but for their activities, would shortly have been lost beyond recovery.

\section{Electrification of the Suburban Railways of Copenhagen}

Tre population of Copenhagen and its suburbs is about 800,000 and they are served by a number of railways, the most important belonging to the State Railway. The problem of electrification presented special difficulties as Denmark is dependent on imported coal for its electric power supply. During recent years, an appreciable amount of electric power has been transmitted from Sweden by 25,000 volt cables which pass under the Sound. When the problem of supply was first investigated, the choice narrowed down to 3,000 volts or 1,500 volts direct current. The latter was chosen, as, although the cost of the overhead equipment was greater, the cost of equipping the cars was less. Hence, when in the future the number of cars is increased, the cost will be less. An account of the system is given by $J$. Kristensen in the Electrical Times of August 23. $\mathrm{He}$ says that all the lattice masts are galvanised, as although it is more expensive than painting it is far more durable. Electrically, the whole system is divided into sections connected through line disconnecting switches. To prevent the electrolysis of neighbouring pipes, extensive precautions are taken. The use of stone ballast keeps the resistance between rail and earth very high, and the resistance of the return system is made as small as possible by joints of heavy copper wire electrically welded to the rails. To prevent interference with telegraph and telephone wires, these have been effectively insulated and placed as far away from the rails as possible. The smallest train is called a 'half-train' and is made up of two motor coaches with a 'trailer' between. It has a seating capacity of 250, and standing room for 200 more. The line Frederiksborg-Klampenborg was opened in April, and the line Copenhagen-Hellerup in May. 